\title{
Age-dependent Occurrence of the Intestinal Ciliate Balantidium coli in Pigs at a Danish Research Farm
}

\author{
By O. Hindsbo ${ }^{1}$, C. V. Nielsen*2, J. Andreassen ${ }^{1}$, A. L. Willingham ${ }^{3}$, M. Bendixen*, M. A. Nielsen* \\ and N. O. Nielsen*
}

${ }^{1}$ Department of Population Ecology, Zoological Institute, University of Copenhagen, Copenhagen, ${ }^{2}$ Department of Veterinary Microbiology, Section of Fish Diseases, ${ }^{3}$ Centre for Experimental Parasitology, The Royal Veterinary and Agricultural University, Frederiksberg, Denmark.

\begin{abstract}
Hindsbo O, Nielsen CV, Andreassen J, Willingham AL, Bendixen M, Nielsen MA, Nielsen NO: Age-dependent occurrence of the intestinal ciliate Balantidium coli in pigs at a Danish research farm. Acta vet. scand. 2000, 41, 79-83. - A cross sectional study of the prevalence and intensity of Balantidium coli in pigs was carried out on a Danish research farm. The prevalence of $B$. coli infection increased from $57 \%$ in suckling piglets to $100 \%$ in most pig groups $\geq 4$ weeks old. The mean number of cysts per gram faeces (CPG) of pigs aged 12 weeks and younger were $\leq 206$, whereas pigs aged 28 weeks and $>52$ weeks had significantly higher counts of $\geq 865$ CPG. Although some lactating sows had very high CPG's, no significant differences in CPG could be detected between the intensities of pregnant sows, lactating sows and empty and dry sows. No human cases of $B$. coli infection have been published in Denmark though it is zoonotic.
\end{abstract}

age; prevalence; intensity; Denmark.

\section{Introduction}

Balantidium coli is a widespread parasitic ciliate in the intestine of many different host species including humans (Areán \& Echevarría 1971). The pig is regarded as the main natural reservoir. In the pig $B$. coli is most frequently found in the lumen of caecum and colon where it usually is asymptomatic (Biagi 1970) but may cause diarrhoea (Yang et al. 1995) and at times be fatal (Soulsby 1968). Occasionally the parasite is causing disease in man. Before antibiotics were available mortality rate of severe human cases was $30 \%$ (Knight 1978). In many cases of human infections (25\%-50\%), contact with pigs is regarded as the likely source of infection (Cross 1990, Kamberoglou et al. 1990). Previously B. coli has been detected in Denmark in the stomach tissue of 1 of 3 pigs showing weight loss (Larsen 1967). Recent exam- inations in Denmark of faecal samples from pigs used for experimental infections with Schistosoma japonicum indicated a high prevalence of B. coli (Willingham et al. 1994). To confirm the significance of this finding a cross sectional survey of the extent of the infection on the donor farm was performed.

\section{Materials and methods}

Faecal samples were taken in 1996 on the same day from Danish Landrace/Yorkshire crossbred pigs reared on the Danish research farm, "Sjælland III". The pigs were housed indoors under specific pathogen-free conditions and fed a standard ration of ground barley with water provided ad libitum. Suckling piglets had access to the sow fodder and were offered separate food when 2 weeks old. Piglets were weaned 
Table 1. Prevalence and intensity of Balantidium coli in age groups of pigs.

\begin{tabular}{lcccccc}
\hline & \multicolumn{6}{c}{ Age in weeks } \\
\cline { 2 - 7 } & $<4$ & 4 & 6 & 12 & 28 & $>52$ \\
\hline Number of pigs & 7 & 6 & 6 & 6 & 6 & 6 \\
Prevalence \% & 57 & 100 & 83 & 100 & 100 & 100 \\
Mean $\mathrm{CPG}^{\text {a }} \pm$ s.d. & $29 \pm 70$ & $72^{\mathrm{b}} \pm 65$ & $206 \pm 376$ & $99 \pm 80$ & $2102 \pm 913$ & $865 \pm 701$ \\
\hline
\end{tabular}

${ }^{a}$ Cysts per gram faeces.

${ }^{b}$ A 21544 CPG pig in the 4 week age group is omitted.

when 4 weeks old, transferred to slated stable floor where they stayed until 12 weeks of age when they were further transferred to concrete floor pens. The pigs showed no sign of diarrhoea. At least 6 faecal samples were taken from each of 6 age classes of pigs: suckling piglets ( $<4$-week-old), weaners (4-week-old), small, medium and large fatteners $(6,12$ and 28-week-old respectively) and empty dry sows (>52-week-old). The samples were stored at $4{ }^{\circ} \mathrm{C}$. Usually, samples were taken directly from the rectum of individual pigs, except from the suckling piglets where litter samples were collected from an area of the floor of the farrowing pen where the sow had no access. Additional samples were taken from pregnant and lactating sows.

For cyst counting, $5 \mathrm{~g}$ faeces were suspended in approximately $100 \mathrm{ml} 0.85 \% \mathrm{NaCl}$ (saline) by gentle, automatic shaking. The suspension was washed with saline through 500, 125 and $44 \mu \mathrm{m}$ mesh Endecott sieves.

The content of the $44 \mu \mathrm{m}$ sieve was resuspended in saline in an $18 \mathrm{~cm}$ high conical sedimentation glass and allowed to sediment for 20 $\min$. The supernatant was removed and the sediment resuspended in about $10 \mathrm{ml}$ saline and centrifuged at $337 \mathrm{~g}(1500 \mathrm{rpm})$ for $1 \mathrm{~min}$. The supernatant was suctioned away and the sediment resuspended to a total of $2.25 \mathrm{ml}$. A sub- sample of 75 or $150 \mu \mathrm{l}$ was transferred to a Sedgewick Rafter counting chamber and the total number of cysts counted using a microscope at $50 \times$ magnification.

In faecal samples kept at $4{ }^{\circ} \mathrm{C}$ for up to 7 days, no difference in cyst numbers could be detected.

Further sedimentation of the supernatant and examination of the waste water and contents of the 125 and $500 \mathrm{~mm}$ sieves resulted in an additional number of cysts, comprising a mean of $3.4 \%$ of the total number of cysts obtained. Thus, a small percentage of cysts were lost during routine faecal processing.

Measurements of protozoan cysts in pig faeces (Soulsby 1968) showed that the cysts of B. coli may be differentiated from other species by their size, being 3 times larger than other known protozoan cysts in pig faeces. We have measured the cysts to be 47-101 $\mu \mathrm{m}$ in length and 44$91 \mu \mathrm{m}$ in width which corresponds to values given by Soulsby (1968). The $44 \mu \mathrm{m}$ sieve therefore separates $B$. coli from other cysts in the faeces. Specimens of cysts were stained with methyl green and the bean shaped macronucleus identified.

For statistical analyses, the Spearman rank correlation coefficient and the Kruskal-Wallis oneway analysis of variance were used (Siegel 1956). 


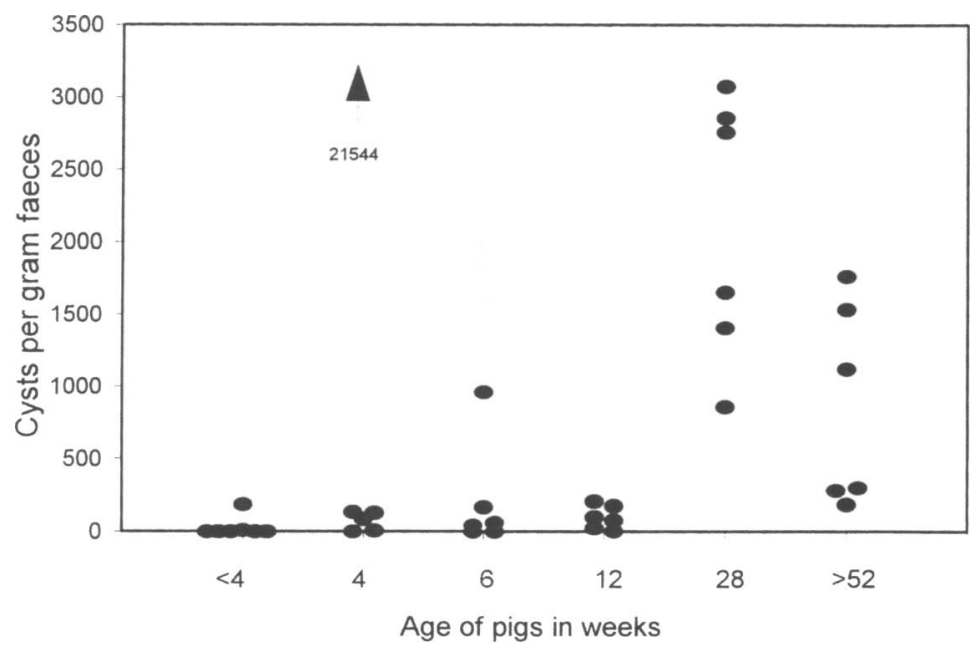

Figure 1. Intensity of Balantidium coli cysts excreted from pigs of different ages. Positive correlation of cysts per gram faeces and pig age is statistically significant $(\mathrm{p}<0.001)$.

\section{Results}

High prevalences of $B$. coli cysts were found in all age groups of pigs already reaching $100 \%$ in 4-week-old piglets. The number of cysts per gram faeces (CPG) was low in pigs 12-weekold and younger (Table 1) except for a very high count of 21,544 CPG in one 4-week-old piglet. Whereas most individual cyst counts in the pigs $\leq 12$-week-old were $<200 \mathrm{CPG}$, counts in the older pigs aged 28 and $>52$ weeks were mostly $>800$ CPG (Fig. 1). This age dependent in- crease in cyst counts was statistically significant (Spearman, $\mathrm{p}<0.001$ ).

The mean cyst count from lactating sows was nearly 3 times higher than that of pregnant sows and empty and dry sows (Table 2) but these differences were not statistically significant (Kruskal-Wallis, $0.3<\mathrm{p}<0.5$ ).

\section{Discussion}

In agreement with Nakauchi (1991), we have found high prevalences of $B$. coli infections in

Table 2. Intensity of Balantidium coli cycts in sow faeces.

\begin{tabular}{lccc}
\hline & \multicolumn{3}{c}{ Group of sow } \\
\cline { 2 - 4 } & Empty and dry $^{\mathrm{a}}$ & Pregnant & Lactating \\
\hline Number of pigs & 6 & 6 & 12 \\
Mean $\mathrm{CPG}^{\mathrm{b}} \pm$ s.d. & $865 \pm 701$ & $834 \pm 775$ & $2145 \pm 2909$ \\
\hline
\end{tabular}

${ }^{a}$ Empty and dry sows are the same pigs as the $>52$-week-old pigs in Table 1.

There are no statistically significant differences in CPG betwen the groups $(0.3<\mathrm{p}<0.5)$.

b Cysts per gram faeces. 
older pigs and a relatively lower prevalence in suckling piglets. Eysker et al. (1994) and $\mathrm{Pa}$ kandl (1994) found no infections in suckling piglets which could be due to their use of less sensitive detection methods. Although unlikely, we can not exclude the possibility of contamination of the piglet samples due to the access of the piglets to the infected sow pens.

A significant increase in the intensity of excreted cysts was found in the older pigs. The mean intensity of the infection in the 28-weekold pigs (2102 CPG) was 4 times higher than that found in 26-week-old pigs by Nakauchi (1991). In addition, we also found a higher prevalence of $100 \%$ in 4 to 28 -week-old pigs, compared to $84 \%$ reported by Nakauchi (1991) in 26-week-old pigs. We have shown that at least $3.4 \%$ of cysts are lost during the faeces processing, and it is therefore possible that discrepancies in the literature are due to some extent to methodological differences.

Encystation may occur outside the host (Knight 1978) and in man usually the trophozoite stage is found, cysts being found in only $10 \%$ of cases (Cross 1990). Autopsies performed in 1998 in 7 pigs from Sjælland III showed that in the last $10 \%$ of the colon a mean value of $57 \%$ (range $21 \%-97 \%$ ) of the $B$. coli population were in the form of cysts. The remaining $B$. coli were still in the trophozoite stage (Hindsbo et al., unpubl.). Cysts per gram faeces is therefore not allways a measure of the total $B$. coli population. This point needs further study.

Experiments in rats indicate that a whole milk diet creates an unfavourable environment for Balantidium obtained from pigs (Shumaker 1930). This may explain the low cyst intensity seen in the suckling piglets. The same author also showed that increasing the carbohydrate portion of the diet caused a considerable increase in the number of balantidia in the caecum of rats. In this respect, it is interesting to note that faeces of the one suckling piglet with an elevated intensity of infection contained plant material like the faecal contents of the sows, which were all infected.

The cyst intensity in one 4-week-old pig was 10 times higher than in adult pigs. We attribute this to unknown individual factors in the pig.

In agreement with Pakandl (1994) we found increased prevalence of $B$. coli infection in weaners and older pigs. As these pigs were fed on carbohydrates we would have expected that the ciliate would multiply in the pigs resulting in an increasing intensity in CPG in $4-12$ weeks old pigs. This was not the case and we have speculated whether it could be of importance that these pigs were kept on slated floors and therefore had little opportunity for coprophagy.

It is known that the lactating host may be more vulnerable to parasite attack (Lloyd 1983). Indeed, the lactating sows tended to have higher CPG's than non-lactating sows, but the individual variability was very high in the sow groups and therefore the difference found between the sow groups was not significant. The finding is supported by similar results on the same farm in 1998 (Hindsbo et al., unpubl.).

Usually, B. coli is regarded as a harmless parasite in pigs, but Mwamba \& Pandey (1977) reported a $B$. coli associated mortality of $30 \%$ $40 \%$ in piglets between 2 to 6 months of age. Agents causing damage to the gut mucosa may encourage tissue invasion, e.g. ascarid larvae in rats (Bogdanovich 1962) or Salmonella and Trichuris in pigs and similar factors may operate in man (Knight 1978). Therefore, the interaction between this very common parasite of the large intestine and mucosa-penetrating colon parasites e.g. Trichuris sais as well as intestinal bacteria should be considered in future experimental studies.

It has been demonstrated that the intestinal ciliate $B$. coli at a Danish pig farm is highly prevalent. Therefore the zoonotic risk of the infection should be given more attention. 


\section{Acknowledgements}

We thank the staff of the Danish Pig Producers and Slaughterhouses Organisation's swine research station "Sjælland III" for assistance with this study and Sylvia Mathiasen for help with the English manuscript.

\section{References}

Areán VM, Echevarría R: Balantidiasis. In: MarcialRojas RA, (ed): Pathology of Protozoal and Helminthic diseases. Williams \& Wilkins, Baltimore, Maryland 1971, pp. 234-251.

Biagi F: Unusual isolates from clinical material Balantidium coli. Annals N.Y. Acad. Sci., 1970, 174, 1023-1026.

Bogdanovich $V V$ : Balantidiasis with concomitant helminthiasis (in experiment). Med. parazitol. i parazitar. bolezni, 1962, 31, 711-715.

Cross JH: Balantidiasis and other intestinal protozoa. In: Warren KS, Mahmoud AAF (eds): Tropical and Geographical Medicine (2.ed.) McGrawHill Inc. 1990, pp. 349-352.

Eysker M, Boerdam GA, Hollanders W, Verheijden JHM: The prevalence of Isospora suis and Strongyloides ransomi in suckling piglets in the Netherlands. The Veterinary Quarterly, 1994, 16, 203205.

Kamberoglou D, Savva S, Adraskelas N, Yannitsiotis $A$, Cocca E: Balantidiasis complicating a case of ulcerative colitis. Am. J. Gastroenterol., 1990, 85 , 765-766.

Knight R: Giardiasis, Isosporiasis and Balantidiasis. In: Marsden PD (ed): Clinics in gastroenterology W B Saunders Comp. 1978, 7, pp. 31-47.

Larsen S: Gastritis in sows due to Hyostrongylus rubidus - in one case associated with Balantidium coli. Acta vet. scand., 1967, 8, 347-359.

Lloyd S: Effect of pregnancy and lactation upon infection. Vet. Immunol. \& Immunopath., 1983, 4, 153-176.

Mwamba T, Pandey VS: Effect of terramycin in balantidiosis of pigs. Ann. Rech. Vet., 1977, 8, 167 169.

Nakauchi K: Prevalence of Balantidium coli infec- tion in different sex and age of pigs in Japan. J. Vet. Med. Sci., 1991, 53, 967-968.

Pakandl M: The prevalence of intestinal protoza in wild and domestic pigs. Vet. Med. - Czech, 1994, 39, 377-380.

Shumaker E: Balantidium coli: Host specificity and relation to the diet of an experimental host. Amer. J. Hyg., 1930, 12, 341-365.

Siegel S: Nonparametric statistics for the behavioural sciences. McGraw-Hill, London, 1956.

Soulsby EJL: Helminths, arthropods and protozoa of domesticated animals. Bailiére Tindall and Cassell, 1968.

Yang Y, Zeng L, Li M, Zhou J: Diarrhoa in piglets and monkeys experimentally infected with Balantidium coli isolated from human faeces. J. Trop. Med. Hyg., 1995, 98, 69-72.

Willingham AL, Johansen $M V$, Vennervald $B J$, Christensen NØ, Nansen P: Experimental infection of Danish Landrace/Yorkshire crossbred pigs with Schistosoma japonicum from the People's Republic of China.. Acta vet. scand., 1994, 35, 395-400.

\section{Sammendrag}

Aldersafhcengig forekomst af tarmciliaten Balantidium coli hos grise på en dansk svineavlsstation.

Forskellige aldersgrupper af grise på den danske stats svineavlsstation "Sjælland III" blev undersøgt for tilstedeværelsen af cyster af tarmciliaten Balantidium coli. Infektionen var meget udbredt, idet cyster kunne påvises hos halvdelen af pattegrisene og hos alle på nær en af de ældre grise.

Intensiteten af cysterne var lav (gennemsnit $\leq 206 / \mathrm{g}$ faeces) hos grise op til 3 måneders alderen, mens den var markant højere hos et halvt år gamle grise og over 1 år gamle grise. Gennemsnitsudskillelsen af cyster var høj hos lakterende søer, men der kunne ikke påvises signifikant forskel fra andre grupper af søer. $B$. coli fra svin kan inficere mennesker, men det zoonotiske aspekt i Danmark er ikke kendt.

\section{(Received February 19, 1998; accepted December 6, 1999).}

Reprints may be obtained from: O. Hindsbo, Department of Population Ecology, Zoological Institute, University of Copenhagen, Universitetsparken 15, DK-2100 Copenhagen Ø, Denmark. E-mail: ohindsbo@zi.ku.dk, tel: +4535321313, fax: +4535321300. 